\title{
COVID-19 AWARENESS AMONG PEOPLE: A KNOWLEDGE QUESTIONNAIRE BASED SURVEY
}

\author{
Pratibha Srivastava \\ Ph.D. Scholar, S.R.K. University Bhopal (M.P.)
}

Article DOI: https://doi.org/10.36713/epra5341

\section{ABSTRACT \\ Government's Activities Success Depends on Community Participation.}

At present in India around 9,07883 active cases of covid-19 and 57,44,693 recovered and discharged from hospital and more than 1 lakh people died because of this disease. By doing this survey researcher came to know about covid-19 awareness level among Indian population. Available data may be helpful get feedback of strategies as implemented by Govt at central, state, district level to fight against this Covid-19 and also will be helpful to reduce mortality and morbidity rate due to this pandemic disease.

It is a descriptive study based on survey approach, Total 5600 People participated in this study, out of these mostly 60.7\% belongs to Uttar Pradesh, 47.1\% belongs to medical profession, 55.4\% Participants belongs to $15-25$ years age group, $65.2 \%$ were female, $52.7 \%$ were graduate. The mean score was 15.71 shows people had good awareness level about covid-19.

\section{INTRODUCTION}

COVID-19 is a pandemic disease. Recently cases have seen all over the world. Daily cases are increasing all over the world. This disease was started from the Wuhan city of China in the month of December 2019. At present there is no particular treatment as well as vaccine for this disease. Various scientists in world are trying to develop vaccine against this virus, some of them even develop this vaccine but still they have to undergo various stages of vaccine testing after that only this will be available for public use as we know it is a long process. But we can't sit quietly till it develops we should take efforts at our level to prevent spread of this disease among people. How we can do so?? By keeping ourselves alert and aware about precautionary measures by following guidelines as provided by Indian government.

By comparing Globally developed cases, in
India cases were controlled in initial stage of this disease it was possible because of good decision taken by our Honorable P.M Mr. Narendra Modi i.e. Lockdown in 4 phases. But during this lockdown period economy of our nation is also affected very badly, in order to cover up that now from 8 June 2020 Govt. of India has given permission to unlock the activities of states with certain guidelines. This is the time for action of common people. Any plan / policy/ program at national level will be successful only when there is full cooperation and participation of community that's why I had chosen this topic for study to find out awareness level of people regarding covid-19.

\section{OBJECTIVES OF THE STUDY}

To assess awareness about Covid-19 among Indian population. 


\section{SJIF Impact Factor: 7.001| ISI I.F.Value:1.241| Journal DOI: 10.36713/epra2016 ISSN: 2455-7838(Online) \\ EPRA International Journal of Research and Development (IJRD)}

\section{METHODOLOGY}

The study was aimed to assess the awareness of Indian population about covid-19. It is a descriptive study, Across-sectional survey approach was used. All the states of India were added in this study except union territories.

Research tools were consisting of demographic variables and 20 knowledge based close ended questionnaire. Questionnaire added in this study depends on guidelines of WHO and Ministry of health and family welfare, Government of India for the prevention and control of covid-19 among common population and also few questions were related to Arogya-setu app, a digital monitoring system for alerting people. With the help of web form data was generated. Convenient sampling technique was used, Knowledge based 20 questionnaires were used, for one-month data was collected through on line and offline mode. 10 questions were based on Awareness about Prevention and control of Covid -19, 7 questions related to Awareness about disease, and 3 questions based on Awareness about Arogya setu app.

\section{FINDINGS OF THE SURVEY}

The mean score was 15.71, which shows people had good awareness level about covid-19.70\% awareness about Prevention and control of Covid -19. $86.57 \%$ Awareness about disease. 82.66\% Awareness about Arogya-Setu app.

\section{Awareness about Prevention and control of Covid -19 :}

1. $100 \%$ Participants have awareness about importance of Hand hygiene for prevention of spread of this disease.

2. $52.9 \%$ knows one-coin shaped amount of an alcohol-based hand sanitizer to be applied on hand.

3. $74.6 \%$ people aware of duration of hand-washing with soap and water.

4. $94.3 \%$ people knows how to wash and dry Homemade / reusable mask.

5. $79.1 \%$ knows about meaning of Social distancing.

6. $76.8 \%$ correct response found of proper Respiratory hygiene while sneezing and coughing.

7. $93.9 \%$ agree stay home while suffered with minor respiratory symptoms.

8. $76.8 \%$ people know about precautionary measures to be used Immediately after using alcohol-based hand sanitize.
9. $89.3 \%$ participants had given response in favour of yoga, meditation and nutritious diet is useful to boost immunity,

10. Only $13 \%$ people knows about the right way of removing the facemask.

Awareness about disease: $86.57 \%$

1. $85 \%$ people know that it is a Pandemic disease.

2. $92.7 \%$ knows Covid-19 is a viral disease.

3. $90.4 \%$ participants know which system is easily affected by this disease.

4. $96.6 \%$ given correct answer, how to diagnose Covid-19.

5. $60.9 \%$ aware about mode of Transmission.

6. $99 \%$ aware about Quarantine period for corona virus disease:

7. $81.8 \%$ had idea when they have to seek medical assistance.

Awareness about Arogya-Setu app: 82.66\%

1. Information about Arogya setu app-96.8\%

2. $70.7 \%$ respondents Knows about Helpline No.

3. Arogya Setu app guide is available in various languages: $80.7 \%$

\section{CONCLUSION}

In this study it was found that, over all people had good awareness about this disease but still awareness to be increase with the use of mass media, news paper, internet etc till all the people have $100 \%$ awareness about this Pandemic. In this study found that information about how to remove mask is very low that is only $13 \%$ people, $29 \%$ people don't know about helpline no. and $47 \%$ people need to know about one-coin shaped amount of sanitizer is to be used for maintaining hand hygiene etc.

Recommendation: This type of study can be done on large sample size. Knowledge, attitude and practice can also be assessed.

Acknowledgment: The authors express their sincere thanks to all the participants of this study.

\section{BIBLIOGRAPHY}

$\begin{array}{ll}\text { 1. } & \text { https://www.ncdc.gov.in/index1.php. } \\ \text { 2. } & \text { https://www.mygov.in/covid-19. } \\ 3 . & \text { https://www.mohfw.gov.in/ } \\ \text { 4. } & \text { https://play.google.com/store/apps/ } \\ \text { 5. } & \text { https://www.who.int/news-room/q-a-detail/q-a-cor } \\ & \text { onaviruses [accessed 2020-04-27] } \\ \text { 6. } & \text { https://www.worldometers.info/coronavirus/ } \\ 7 . & \text { https://www.worldometers.info/coronavirus/ }\end{array}$ 


\section{EPRA International Journal of Research and Development (IJRD)}

Volume: 5 | Issue: 10 | October 2020

- Peer Reviewed Journal

8. https://www.statnews.com/2020/04/05/deficit-publ ic-health-workers-no-way-to-fight-covid-19/

9. https://www.snopes.com/fact-check/trump-fire-pan demic-team/

10. http://www.ijmr.org.in/article.asp/2020;volume 